\title{
Investigation of mechanical, thermal and electrical parameters of gel combustion-derived cubic zirconia/epoxy resin composites for high-voltage insulation
}

\section{(Investigação de parâmetros mecânicos, térmicos e elétricos de compósitos zircônia cúbica derivada de gel-combustão/resina epóxi para isolamento de alta tensão)}

\author{
J.S. Sagar ${ }^{1}$, S. J. Kashyap ${ }^{1}$, G. M. Madhu ${ }^{1 *}$, Pradipkumar Dixit ${ }^{2}$ \\ ${ }^{I}$ Ramaiah Institute of Technology, Department of Chemical Engineering, M S Ramaiah Nagar, \\ MSRIT Post, Bengaluru, 560054, Karnataka, India \\ ${ }^{2}$ Ramaiah Institute of Technology, Department of Electrical \& Electronics Engineering, Karnataka, India
}

\begin{abstract}
The present study deals with the fabrication of epoxy composites reinforced with synthesized nano-zirconia, and to study their properties for high-voltage applications. The epoxy composites were extensively characterized to understand the morphology, mechanical, thermal, and electrical insulating behavior. The surface morphology and molecular structure of the nanoparticle and its interaction with the base matrix ware investigated by scanning electron microscopy, Fourier-transform infrared spectroscopy, and X-ray diffraction (XRD). XRD profiles confirmed that particles were crystalline and nanosized. Moreover, the tensile characteristics were analyzed using various theoretical models that predict the stiffness of these composites. The glass transition temperature of the epoxy $/ \mathrm{ZrO}_{2}$ composite increased with the increase in nanofiller content. The AC breakdown voltage reached a maximum of $14.8 \mathrm{kV}$ for $2 \mathrm{wt} \% \mathrm{ZrO}_{2}$ composite. The prepared composites have the potential to act as high-performance insulation materials.

Keywords: nanofiller composite, $\mathrm{ZrO}_{2}$, mechanical properties, thermal properties, gel combustion process.
\end{abstract}

Resumo

Este estudo trata da fabricação de compósitos de epóxi reforçado com nano-zircônia sintetizada, e o estudo de suas propriedades para aplicações de alta tensão. Os compósitos de epóxi foram extensivamente caracterizados para entender a morfologia e o comportamento mecânico, térmico e elétrico de isolamento. A morfologia da superfície e a estrutura molecular da nanopartícula e sua interação com a matriz foram investigadas por microscopia eletrônica de varredura, espectroscopia no infravermelho por transformada de Fourier e difração de raios $X(D R X)$. Os padrões de DRX confirmaram que as partículas foram cristalinas com dimensões nanométricas. Além disso, as características de tração foram analisadas usando vários modelos teóricos que preveem a rigidez desses compósitos. A temperatura de transição vítrea do compósito epóxi/ZrO aumentou com o aumento do teor de nanofíler. A tensão de ruptura dielétrica em corrente alternada atingiu máximo de 14,8 kV para o compósito com $2 \%$ em massa de $\mathrm{ZrO}_{2}$. Os compósitos preparados têm potencial de atuar como materiais de isolamento de alto desempenho.

Palavras-chave: compósito nanofíler, $\mathrm{ZrO}_{2}$, propriedades mecânicas, propriedades térmicas, processo gel-combustão.

\section{INTRODUCTION}

The ever-increasing applications of polymeric materials with enhanced mechanical and thermal properties have always been a major objective from both academic and industrial points of view. Due to this rising popularity, the thermoset epoxy resins are widely preferred for industrial applications such as adhesives, construction materials, electrical insulation, laminates, aviation and so on [1-4]. Nonetheless, the brittleness of the cured pristine epoxy

*gmmadhu@gmail.com

Dhttps://orcid.org/0000-0003-3937-7924 restricts its application in the real world. To counteract these problems, several techniques for toughening these epoxy systems have been introduced in the past few decades by industrialists as well as researchers. One such technique was to incorporate different modifiers derived from rubbers and thermoplastics, but these mixtures failed to outperform due to the high viscosity of the epoxy monomer mixture, which compromised its thermal properties [5,6]. Enhancing the properties of epoxy resins was proposed by incorporating dispersed inorganic nanoparticles into the epoxy matrix. Nanofillers are considered to improve various parameters of the base matrix which include mechanical, electrical, and thermal behavior due to their smaller size effects [79]. There has been plenty of research associated with 
improving the overall performance of the polymer matrices by dispersion of inorganic nanofillers which has brought significant changes to their physical properties [10-13].

Many researchers reported the enhancement of structural and mechanical parameters of epoxy resins by the addition of a small amount of nano-reinforcements such as carbon nanotubes [13], $\mathrm{Al}_{2} \mathrm{O}_{3}[14], \mathrm{SiO}_{2}$ [15], $\mathrm{TiO}_{2}$ [16], clay [17], fly ash [18], etc. It can be implied that these nanofillers, even at low concentrations, show good thermal and mechanical properties when incorporated into thermoset polymers. This might probably be due to the uniform distribution of the nanofillers in the dense epoxy cross-linked networks resulting in appreciable enhancement of thermo-mechanical properties of the composites. Among several nanofillers, zirconium dioxide $\left(\mathrm{ZrO}_{2}\right)$ can be employed as a promising reinforcement particle due to its characteristics like excellent stiffness and good chemical resistance along with elevated modulus, high fracture toughness, excellent wear resistance, and thermal stability [19-22]. Medina et al. [23] reported a $37 \%$ increase in the tensile modulus and a $100 \%$ increase in the fracture toughness with epoxy composite containing $10 \%$ by volume of nano- $\mathrm{ZrO}_{2}$ compared to the neat epoxy. Furthermore, they also reported an eightfold increase in the glass transition temperature $\left(\mathrm{T}_{\mathrm{g}}\right)$ with $8 \mathrm{vol} \% \mathrm{ZrO}_{2}$ in the epoxy matrix. Halder et al. [24, 25] studied the influence of different mixing procedures on the morphological and tensile characteristics of the epoxy/ZrO 2 composites. They reported that the dispersion of nanoparticles was fairly good with ultrasonic dual mode mixing compared to mechanical mixing. They also reported that the tensile strength increased by $57 \%$ for 10 wt $\%$ of $\mathrm{ZrO}_{2}$ relative to neat epoxy, but further increase in the filler content diminished the tensile properties as well as the fracture properties due to increased particle clusters. They further investigated the effect of silanemodified $\mathrm{ZrO}_{2}$ (SZN) on epoxy/glass fiber composites [26]. It was concluded that the incorporation of SZNs into the glass fiber epoxy matrix resulted in a $27 \%$ to $110 \%$ increase in the tensile strength, stiffness and toughness with respect to the control sample. Meanwhile, Chung et al. [27] and Tao et al. [28] studied epoxy incorporated with surface-modified $\mathrm{ZrO}_{2}$ composites as LED encapsulants and concluded that refractive index and light output power increased with increase in loading percentage. Li et al. [29] studied the cryogenic mechanical parameters of epoxy/ZrO composites via surface modification of nano- $\mathrm{ZrO}_{2}$ with (3-aminopropyl)triethoxysilane (APTS). They observed a $26.4 \%$ increase in tensile strength and a $21.1 \%$ increase in failure strain compared to the control sample at cryogenic temperatures. Recently, Ma et al. [30] synthesized encapsulated nanozirconia using a silane coupling reagent and reported that the optimal mechanical properties were achieved at $3 \mathrm{wt} \%$ of $\mathrm{ZrO}_{2}$ in the epoxy matrix. In summary, there are published reports mostly on the evaluation of the tensile parameters of epoxy/ZrO and composites. As mentioned before, electrical insulation is one of the major applications of epoxy systems as they are widely used in electrical instruments. During operation, a high amount of electrical stress coupled with thermal stress is exerted due to the high shear exerted because of the conduction of high current and vibrational stress occurring due to the mechanical agitation of electrical equipment. Therefore, it is necessary for the composite to withstand high mechanical and electrical stress during its usage.

The present study aimed at the synthesis of nanoparticles and preparation of epoxy composites to investigate the breakdown voltage and the thermal stability of the fabricated epoxy resins loaded with varying filler $\left(\mathrm{ZrO}_{2}\right)$ concentration. In addition, the surface morphology of the synthesized nanopowders and the composites were characterized by scanning electron microscopy (SEM). Fourier-transform infrared spectroscopy (FTIR) was performed to understand the possible structural manipulations between the bulk epoxy and nanoparticles. These composites were also subjected to X-ray diffraction (XRD) in order to understand the molecular structure and crystallinity. The tensile and compressive parameters of the composites were evaluated in detail to assess the effect of filler concentration on the epoxy matrix. Various theoretical models were applied to analyze the experimental results of mechanical parameters.

\section{EXPERIMENTAL}

Reagents and materials: all chemicals were of analytical grade and used without further purification: zirconium nitrate trihydrate $\left[\mathrm{Zr}\left(\mathrm{NO}_{3}\right)_{4} \cdot 3 \mathrm{H}_{2} \mathrm{O}, \geq 99 \%\right.$, Loba Chemie]; glycine $\left(\mathrm{CH}_{2} \mathrm{NH}_{2} \mathrm{COOH}\right.$, Fine Chemicals); Lapox-L12 (diglycidyl ether of bisphenol-A, Atul Polymers Div., India) used as the epoxy resin; TETA K-6 (triethylenetetramine, Atul) used as a hardener; and double-distilled water employed throughout the experiments.

Synthesis of $\mathrm{ZrO}_{2}$ nanoparticles: $\mathrm{ZrO}_{2}$ nanoparticles were synthesized via the gel combustion chemical route. The overall process involved mainly 4 steps: formation of a homogeneous solution at $50-55{ }^{\circ} \mathrm{C}$; formation of a dried gel at $110{ }^{\circ} \mathrm{C}$; combustion of the dried gel at $400{ }^{\circ} \mathrm{C}$; and calcination of the product at $600{ }^{\circ} \mathrm{C}$. In a typical synthesis, zirconium (IV) nitrate trihydrate (10.794 g) was mixed with glycine $(1.168 \mathrm{~g})$, which was used as a fuel to promote combustion. The fuel to nitrate $(\mathrm{F} / \mathrm{N})$ ratio was kept constant at 2:1. This mixture was taken in a $250 \mathrm{~mL}$ beaker, and $100 \mathrm{~mL}$ of double-distilled water was added. The beaker containing the mixture was kept in a muffle furnace for 10 min maintained at $400{ }^{\circ} \mathrm{C}$. The beaker was then taken out and cooled to room temperature for $30 \mathrm{~min}$. After this, the particles were taken in a crucible and ground into a fine powder. The chemical reaction involved in the synthesis of $\mathrm{ZrO}_{2}$ by the combustion route is represented in Eq. A. The synthesized powder was calcined at $600{ }^{\circ} \mathrm{C}$ for $40 \mathrm{~min}$. Finally, after cooling to room temperature, $\mathrm{ZrO}_{2}$ nanoparticles were obtained. 


$$
\begin{aligned}
& 9 \mathrm{Zr}\left(\mathrm{NO}_{3}\right)_{4} \cdot 3 \mathrm{H}_{2} \mathrm{O}+20 \mathrm{CH}_{2} \mathrm{NH}_{2} \mathrm{COOH} \rightarrow \\
& 9 \mathrm{ZrO}_{2}+40 \mathrm{CO}_{2}+56 \mathrm{~N}_{2}+77 \mathrm{H}_{2} \mathrm{O}
\end{aligned}
$$

Preparation of epoxy/ $/ \mathrm{ZrO}_{2}$ composites: different fractions $(2,4,6,8$, and $10 \mathrm{wt} \%)$ of zirconium oxide nanoparticles were added to the epoxy prepolymer and subjected to mechanical stirring for $20 \mathrm{~min}$. This suspension was then sonicated for 40 min to obtain a uniform distribution of nanoparticles in the epoxy matrix. Then, the mixture was cured at room temperature, and $10 \%$ by volume of hardener was added. The as-prepared solution was poured into a suitable mold coated with Teflon sheets and was allowed to cure for 24 $\mathrm{h}$. The composite laminates of dimensions $150 \times 200 \times 3 \mathrm{~mm}$ were made.

Investigation techniques: FTIR spectra of the epoxy/ $\mathrm{ZrO}_{2}$ composites were measured in the range of 4000$400 \mathrm{~cm}^{-1}$ using a spectrometer (Impact-410, Bruker, USA) in transmittance mode with a resolution of $4 \mathrm{~cm}^{-1}$. X-ray diffraction patterns of the nanoparticle and composites were obtained using a diffractometer (X'Pert ${ }^{3}$, PANalytical) with Ni-filtered $\mathrm{CuK} \alpha$ radiation $(40 \mathrm{kV}, 20 \mathrm{~mA})$ in the range of $0-80^{\circ}$ at a scanning rate of $2 \mathrm{~s} / \mathrm{step}$ and a step size of $0.02^{\circ}$. The composite morphologies were investigated by scanning electron microscopy (SEM) using a microscope (ESEM Quanta 200, FEI, USA) operating at a voltage of $20 \mathrm{kV}$. Elemental analysis of the as-synthesized nanopowder was performed using an energy dispersive X-ray (EDX) analyzer attached to the SEM instrument. Tensile testing of the composites was carried out according to the ASTM D638 standard at a crosshead speed of $10 \mathrm{~mm} / \mathrm{min}$ (PC-2000, Kudale UTM). The gauge length between the grips was kept constant at $20 \mathrm{~mm}$. Compression testing of the composites was carried out as per the ASTM D695 standard with a crosshead speed of $2 \mathrm{~mm} / \mathrm{min}$. The tests were conducted with 3 specimens for each sample, and the average values were reported. The glass transition temperature $\left(\mathrm{T}_{\mathrm{g}}\right)$ of the composites was evaluated through a differential scanning calorimetry (DSC) according to the ASTM E1356 (Q200, TA Instr.). AC breakdown strength was estimated using an AC breakdown experimental setup as per ASTM D3756-97.

\section{RESULTS AND DISCUSSION}

Infrared spectroscopy: FTIR spectra of the composites loaded with $0-10 \mathrm{wt} \%$ of nanoparticles are shown in Fig. 1 . The observable absorption bands in the range of 1019$1094 \mathrm{~cm}^{-1}$ can be assigned to the aromatic $\mathrm{C}=\mathrm{O}$ stretching vibration of the epoxy polymer [31]. A peak at 1227-1382 $\mathrm{cm}^{-1}$ corresponded to the $\mathrm{C}=\mathrm{C}$ and $\mathrm{C}-\mathrm{N}$ stretching of the aromatic group [32]. Further, the band vibration in the range of $1602-1672 \mathrm{~cm}^{-1}$ showed the $\mathrm{C}=\mathrm{C}$ stretching of the bulk matrix. The bands in the ranges of 2849-2853 and 2915$2933 \mathrm{~cm}^{-1}$ can be attributed to the $-\mathrm{CH}_{2}$ stretching [33]. Absorbance bands observed at $3422 \mathrm{~cm}^{-1}$ indicated the $\mathrm{OH}$ stretching of pure epoxy [34]. Furthermore, the $\mathrm{Zr}-\mathrm{OH}$ stretching band was assigned at the range of $3357-3398 \mathrm{~cm}^{-1}$ [31], and a band at the range of $622-755 \mathrm{~cm}^{-1}$ corresponded to the $\mathrm{Zr}-\mathrm{O}$ stretching vibration band [32]. The additional bands observed in the range of $815-822 \mathrm{~cm}^{-1}$ can be attributed to the presence of inert amine in the matrix. These bands were not observed for pristine epoxy, which might be possible due to the formation of an amino-rich interface region around the nanoparticles in the bulk epoxy in the composites [25]. These results confirmed the adhesion of $\mathrm{ZrO}_{2}$ nanoparticles with the epoxy matrix.

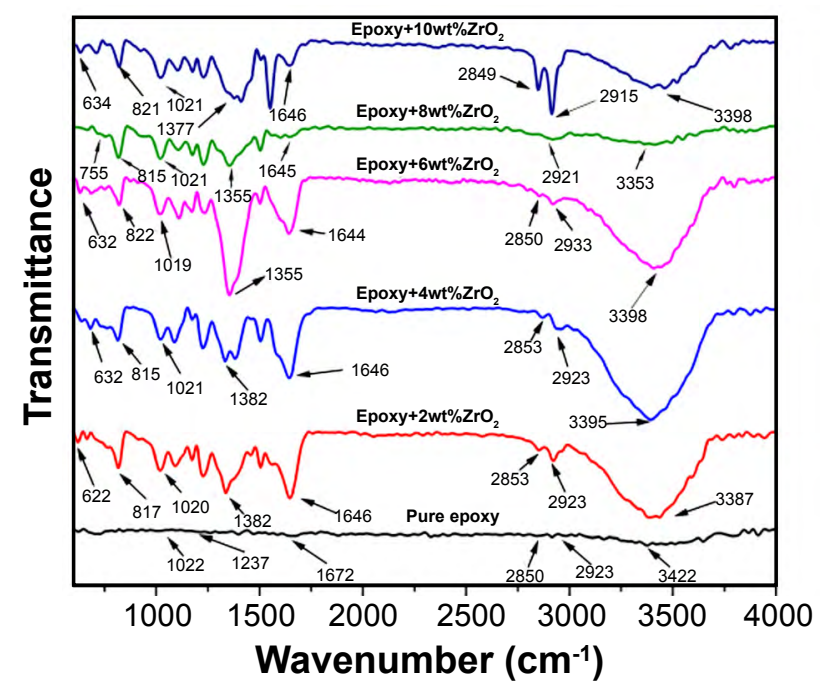

Figure 1: FTIR spectra of epoxy and $\mathrm{ZrO}_{2}$-epoxy composites. [Figura 1: Espectros de FTIR do epóxi e compósitos $\mathrm{ZrO}_{2}$-epóxi.]

$X$-ray diffraction: XRD pattern of the synthesized $\mathrm{ZrO}_{2}$ nanoparticles calcined at $600{ }^{\circ} \mathrm{C}$ is shown in Fig. 2. The diffraction peaks observed at $2 \theta=30.21^{\circ}, 34.95^{\circ}, 50.38^{\circ}$, and $59.78^{\circ}$ largely corresponded to the (111), (200), (220), and (311) planes, respectively, of the cubic phase of $\mathrm{ZrO}_{2}$ which were in good agreement with the JCPDS data, powder diffraction file No. 27-0997, and also with previous research findings [33]. The average crystallite size of particles was estimated using Scherrer equation:

$$
\mathrm{D}=\frac{\mathrm{k} \cdot \lambda}{\beta \cdot \cos \theta}
$$

where $\mathrm{D}$ is crystallite size, $\mathrm{k}$ is the Scherrer constant (0.89), $\lambda$ is the wavelength of X-ray $(1.540598 \AA), \beta$ is the fullwidth at half maxima (FWHM) of the diffraction peak, and $\theta$ is the Bragg angle. The average crystallite size of the nanoparticles was calculated to be $11.8 \mathrm{~nm}$.

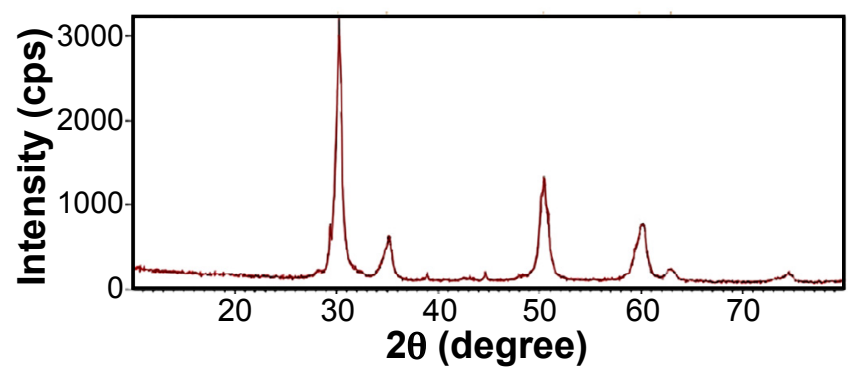

Figure 2: XRD pattern of as-synthesized $\mathrm{ZrO}_{2}$ nanoparticles. [Figura 2: Padrão de DRX das nanopartículas sintetizadas de $\left.\mathrm{ZrO}_{2}.\right]$ 
XRD patterns of pure epoxy and epoxy/ZrO $/ \mathrm{rO}_{2}$ composites having 2, 4, 6, 8, and $10 \mathrm{wt} \%$ of $\mathrm{ZrO}_{2}$ are shown in Fig. 3. Generally, alteration of crystallinity and surface morphology of the polymer matrix was observed after the incorporation of inorganic nanoparticles. From the XRD profiles, the peaks at $2 \theta \sim 30.2^{\circ}$ showed that the nanoparticles were successfully incorporated into the epoxy base matrix. From these data, one can notice that the sharp peaks were not very intense for the epoxy matrix incorporated with 2 wt $\% \mathrm{ZrO}_{2}$ nanoparticles due to the large weight percentage of the amorphous epoxy matrix. Further increase in the fraction of the nanoparticles in the base matrix decreased the broad, amorphous band of the base matrix and increased the intensity of peaks of the inorganic nanofiller. The other peaks of $\mathrm{ZrO}_{2}$ at $2 \theta 50.38^{\circ}$ and $59.78^{\circ}$, which were not clearly visible at low concentration $(2 \mathrm{wt} \%)$, increased with the increase in the filler concentration implying a higher degree of crystallinity. The approximate crystallinity of the doped composites was calculated by finding out the area of the crystalline peaks and dividing it by the total area of all the peaks in the profile. The highest percentage of crystallinity was observed for epoxy/10 wt $\% \mathrm{ZrO}_{2}$ with a calculated value of $26.1 \%$ and the lowest crystallinity was observed for epoxy $/ 2 \mathrm{wt} \% \mathrm{ZrO}_{2}$ with a value of $12.2 \%$. Epoxy filled with 4,6 , and 8 wt $\%$ of $\mathrm{ZrO}_{2}$ had crystallinity of $14.3 \%$, $19.1 \%$, and $18.9 \%$, respectively. It was observed that as the filler content in the epoxy matrix increased, the amorphous nature of the composites was gradually decreased and the crystallinity of the composites was slightly elevated. The incorporation of $\mathrm{ZrO}_{2}$ nanoparticles also resulted in no observable phase transformation or structural manipulation.

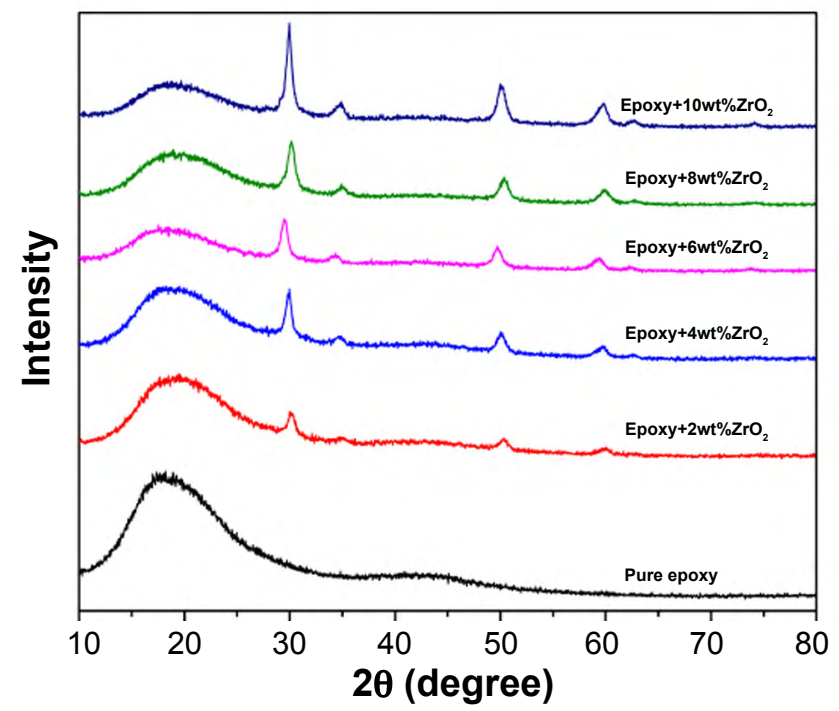

Figure 3: XRD patterns of the composites.

[Figura 3: Padrões de DRX dos compósitos.]

Scanning electron microscopy: Fig. 4 shows SEM images of the $\mathrm{ZrO}_{2}$ nanoparticles synthesized by the gel combustion method. The nanoparticles appeared to be agglomerated to a certain extent, with the presence of small voids and roughness. These characteristics were due to the huge quantity of gases released during the combustion reaction. A substantial amount of gases escaping out assisted the formation of tiny particles while the heat released was a major factor for the crystal growth. Agglomeration of these nanoparticles is generally accounted to be a common route to reduce their surface free energy [35]. Fig. 5 shows the EDX spectrum of combustion-derived $\mathrm{ZrO}_{2}$ nanopowder. The $\mathrm{Zr}$ and $\mathrm{O}$ peaks were clearly found, which suggested that pure $\mathrm{ZrO}_{2}$ nanoparticles were obtained from the combustion synthesis route. Peak indexing of elements zirconium at $\sim 1.9 \mathrm{keV}$ and oxygen at $\sim 0.6 \mathrm{keV}$ can be observed in Fig. 5 . The compositions obtained in the weight percentage of the elements were zirconium $61.4 \%$ and oxygen $38.6 \%$.
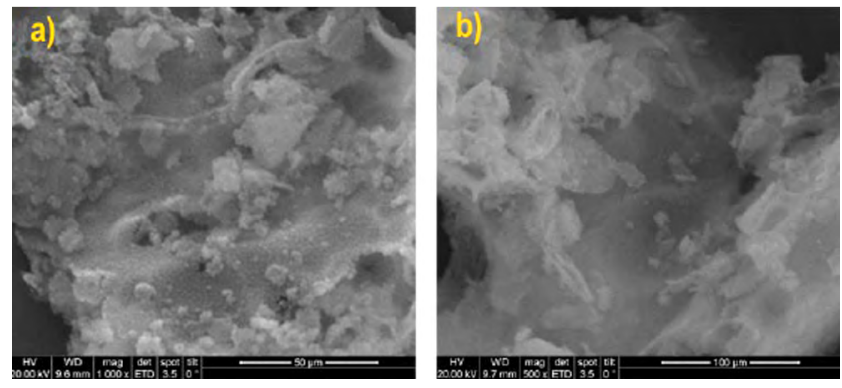

Figure 4: SEM images of $\mathrm{ZrO}_{2}$ nanoparticles.

[Figura 4: Imagens de MEV de nanopartículas de $\mathrm{ZrO}_{2}$.]

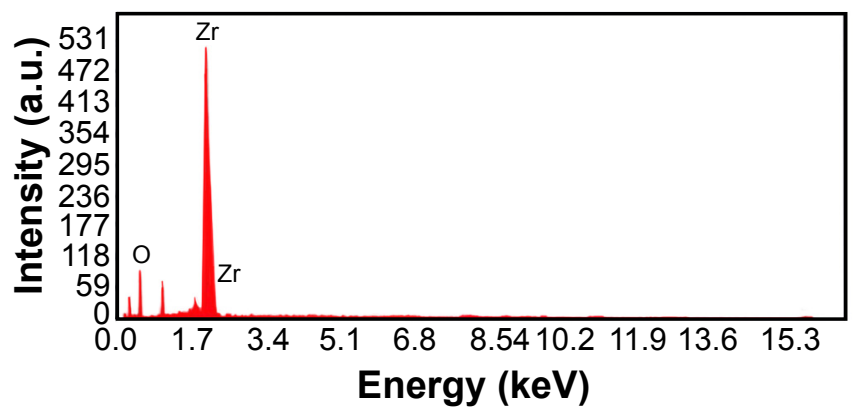

Figure 5: EDX spectrum of as-synthesized $\mathrm{ZrO}_{2}$ nanopowder. [Figura 5: Espectro de EDX do nanopó sintetizado de $\mathrm{ZrO}_{2}$.]

Fig. 6 shows SEM micrographs of composites showing the presence of dispersed nanoparticles in the epoxy matrix. From Figs. $6 \mathrm{a}$ and $6 \mathrm{~b}$, it can be deduced that the nanoparticles were homogeneously distributed on the surface of the epoxy matrix at low concentrations ( 2 and 4 wt $\%$ of $\mathrm{ZrO}_{2}$ ), with no observable agglomeration or cluster formation. The composites exhibited smooth surfaces with microsized voids developed at relatively low doping content. However, the agglomeration of nanoparticles was seen at higher concentrations in the epoxy matrix. In Figs. 6c to 6 e, aggregations or chunks of nanoparticles are observed, implying non-uniform distribution of nanoparticles (6 to 10 wt $\%$ of $\mathrm{ZrO}_{2}$ ) in the epoxy matrix. The tendency to form clusters of nanoparticles in epoxy is mainly due to the van der Waals force between the nanopowders and viscosity of the resin [10]. These nanoparticles were observed to be distributed closely to each other in the epoxy matrix, with an increase in $\mathrm{ZrO}_{2}$ content. As the agglomeration increased, the 
interparticle distance decreased, leading to weak distribution and interlinkage between the filler and the epoxy matrix. From the cross-sectional SEM micrographs (Fig. 7), the nanoparticles appeared to be dispersed uniformly throughout the epoxy matrix. Agglomerations of $\mathrm{ZrO}_{2}$ nanoparticles were not quite observed in the cross-sectional views of SEM images even at relatively higher concentrations implying good adhesion and uniform distribution inside the bulk epoxy. The observed compatibility between the epoxy polymer matrix and the dopant in these images might have a positive effect on the mechanical parameters of the composites [36]. Although Fig. 7e depicting the crosssectional view of epoxy loaded with $10 \mathrm{wt} \%$ of $\mathrm{ZrO}_{2}$ shows some agglomeration, it can be accounted for the increased filler concentration resulting in the decreased interparticle distance inside the epoxy matrix. A common observation from the SEM images was the tendency of the nanoparticles to disperse closely to each other in the epoxy matrix with the increase in nanofiller concentration.

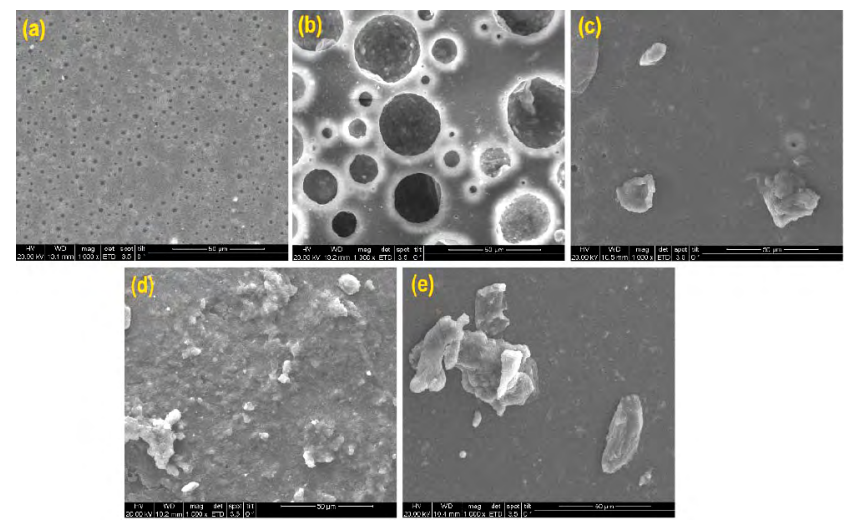

Figure 6: SEM micrographs of epoxy resin loaded with $\mathrm{ZrO}_{2}$ nanoparticles at: a) $2 \mathrm{wt} \%$; b) $4 \mathrm{wt} \%$; c) $6 \mathrm{wt} \%$; d) $8 \mathrm{wt} \%$; and e) $10 \mathrm{wt} \%$.

[Figura 6: Micrografias de MEV de resina epóxi com nanopartículas de $\mathrm{ZrO}_{2}$ em fração mássica de: a) 2\%; b) 4\%; c) 6\%; d) 8\%; e e) 10\%.]

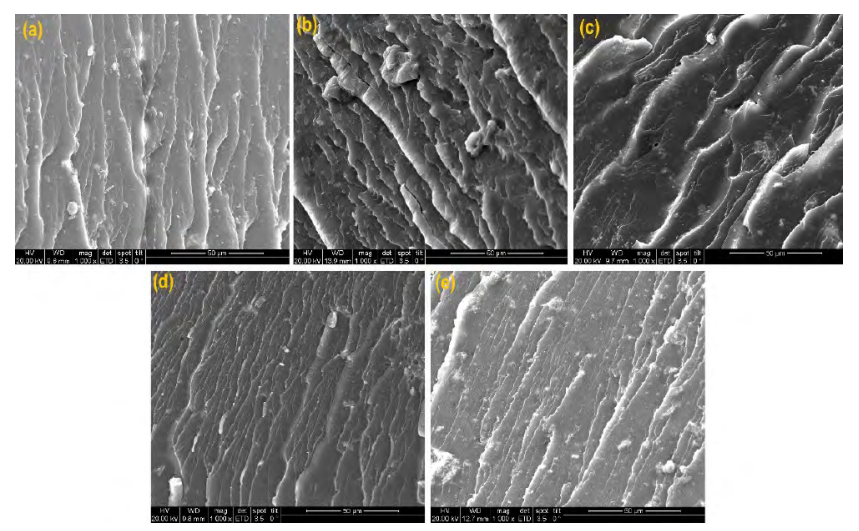

Figure 7: SEM images of the cross-section of epoxy resin with $\mathrm{ZrO}_{2}$ nanoparticles at: a) $2 \mathrm{wt} \%$; b) $4 \mathrm{wt} \%$; c) $6 \mathrm{wt} \%$; d) $8 \mathrm{wt} \%$; and e) $10 \mathrm{wt} \%$.

[Figura 7: Imagens de MEV da seção transversal de resina epóxi com nanopartículas de $\mathrm{ZrO}_{2}$ em fração mássica de: a) 2\%; b) 4\%; c) $6 \%$; d) $8 \%$; e e) $10 \%$.]
Tensile properties: the mechanical properties of polymer composites are an important factor in determining its suitability and applications in the real world. Fig. 8 shows the tensile stress-strain curve of the fabricated composites. It was observed that the tensile stress increased linearly with the tensile strain until the breakpoint, showing typical stress-strain characteristics of polymer composites. The various mechanical properties of epoxy $/ \mathrm{ZrO}_{2}$ composites like tensile strength, tensile modulus, elongation at break, and toughness are shown in Fig. 9. Fig. 9a shows the tensile strength of the composites loaded with nano- $\mathrm{ZrO}_{2}$ at various concentrations. It was observed that the tensile strength of the composites increased linearly with respect to the filler content. The composites doped with $\mathrm{ZrO}_{2}$ showed remarkably elevated tensile strengths compared to that of the control sample. It can be hypothesized from these findings that the tensile strength of the composites increases with an increase in filler content in the matrix. Epoxy loaded with $10 \mathrm{wt} \% \mathrm{ZrO}_{2}$ demonstrated the highest tensile strength with a whopping $125 \%$ enhancement compared to pure epoxy. However, epoxy $/ 2 \mathrm{wt} \% \mathrm{ZrO}_{2}$ showed only a $40 \%$ increase in the tensile strength, which can be justified based on the amount of filler content in the matrix. Epoxy loaded with 6 and $8 \mathrm{wt} \% \mathrm{ZrO}_{2}$ showed $98 \%$ and $121 \%$ increase in tensile strength, respectively, with respect to the filler-free epoxy. A steady increase in the tensile strength was observed. The tensile strength enhanced even at high $\mathrm{ZrO}_{2}$ fractions in the matrix proving that the agglomerations of nanoparticles observed in the SEM images did not seem to cause early fracture of the composites. It appears that the interparticle linkage did not play a significant role in the enhancement of tensile strength compared to particle-polymer interaction. However, the tensile strengths of epoxy loaded with 8 and $10 \mathrm{wt} \%$ of $\mathrm{ZrO}_{2}$ were anomalously close $(\sim 4 \%)$ compared to the overall linearity observed, raising concerns on the dispersion of nanofillers at high concentrations.

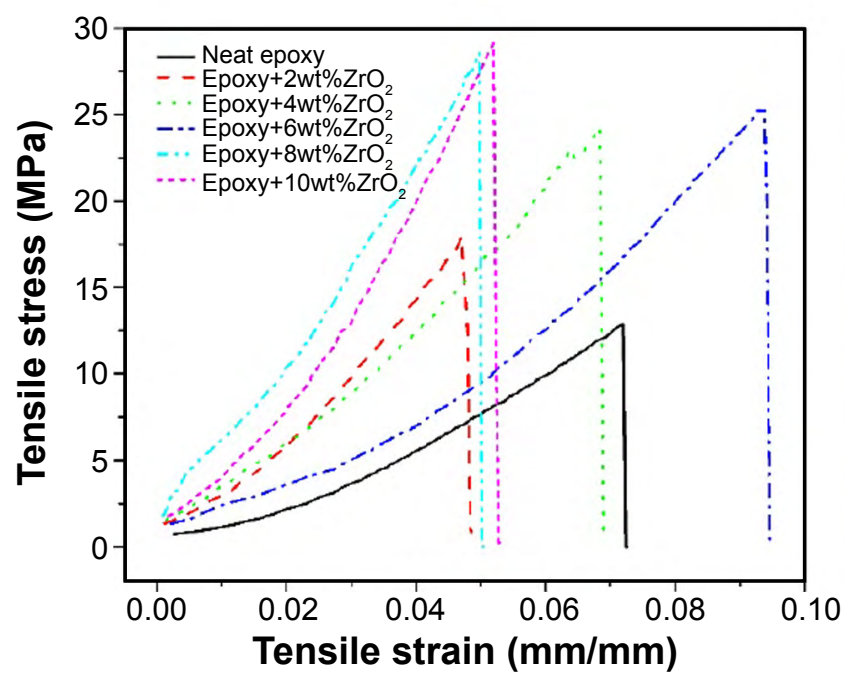

Figure 8: Tensile stress-strain curves of neat epoxy and composites with $\mathrm{ZrO}_{2}$ at various contents.

[Figura 8: Curvas tensão-deformação em tração de epóxi puro e compósitos com diferentes teores de $\mathrm{ZrO}_{2}$.] 

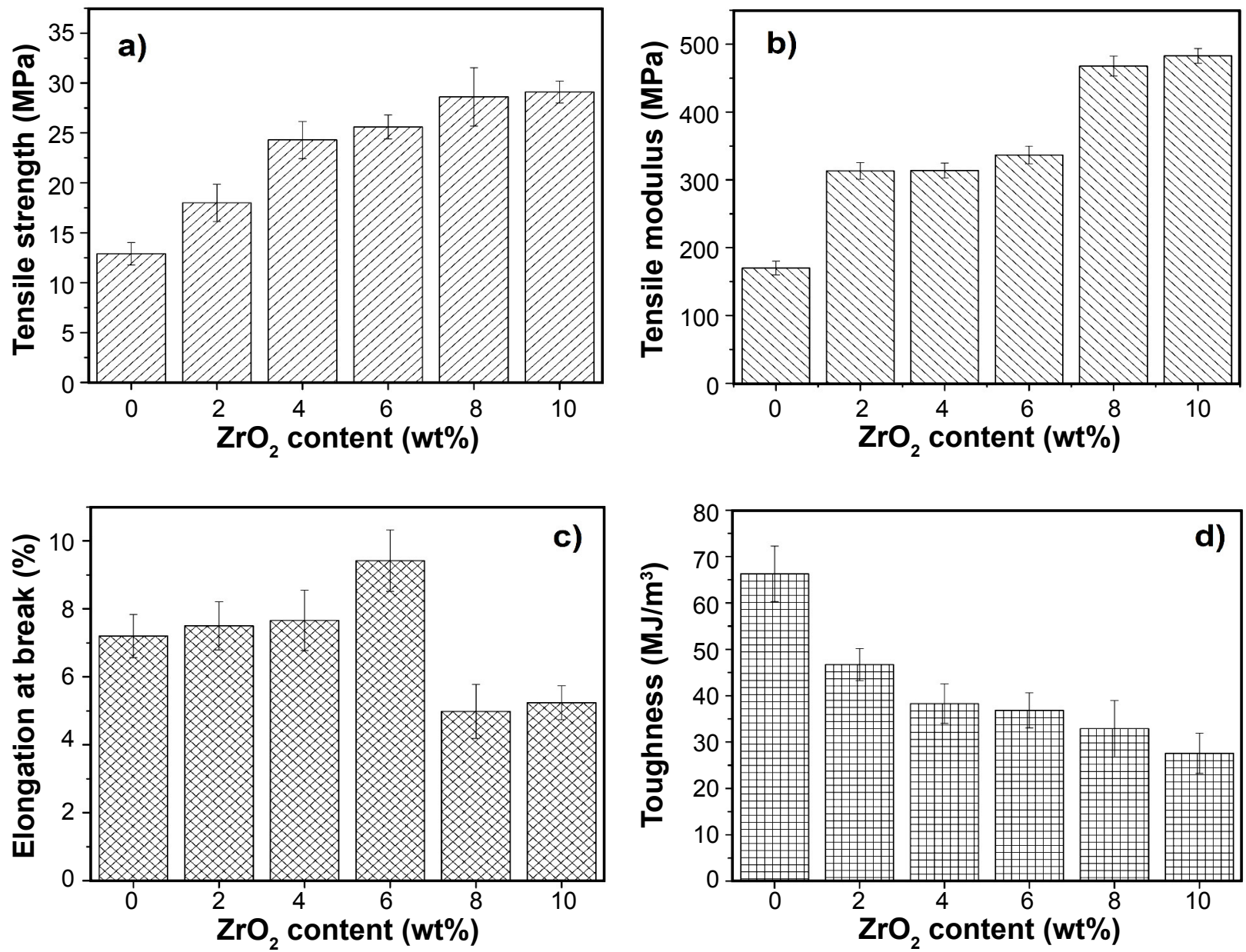

Figure 9: Results of tensile strength (a), tensile modulus (b), elongation at break (c), and toughness (d) of composites with different $\mathrm{ZrO}_{2}$ content.

[Figura 9: Resultados da resistência à tração (a), módulo de elasticidade em tração (b), alongamento na ruptura (c) e tenacidade (d) de compósitos com diferentes teores de $\mathrm{ZrO}_{2}$.]

The tensile moduli of the composites with varying concentrations of $\mathrm{ZrO}_{2}$ are shown in Fig. 9b. Pristine epoxy had relatively the lowest tensile modulus of $170 \mathrm{MPa}$, and epoxy-containing $10 \mathrm{wt} \%$ of $\mathrm{ZrO}_{2}$ showed the maximum tensile modulus. There was no observable trend in the tensile modulus values with respect to the filler concentration. However, the maximum tensile modulus shown by the doped composite, i.e., with $10 \mathrm{wt} \%$ of $\mathrm{ZrO}_{2}$ content was $\sim 184 \%$ higher than the pristine sample, but there was no linearity observed in the values of tensile modulus. The epoxy-containing 2 and $4 \mathrm{wt} \% \mathrm{ZrO}_{2}$ had more or less the same values of tensile modulus ( $\sim 84 \%$ more than filler-free sample). There was a $98 \%$ increase in the tensile modulus of epoxy $/ 6 \mathrm{wt} \% \mathrm{ZrO}_{2}$ compared to the control sample, after which the tensile modulus abruptly increased for the epoxycontaining 8 and $10 \mathrm{wt} \% \mathrm{ZrO}_{2}$. The peculiarity observed in these values may be due to the bonding of immobilized epoxy chains with aggregated nanoparticles in the matrix [37]. The elongation at break appeared to have an optimal value of $9.4 \%$ at $6 \mathrm{wt} \%$ filler concentration in the base matrix as shown in Fig. 9c. The elongation at catastrophic break decreased beyond that point, reaching $5 \%$, which was $\sim 47 \%$ and $30 \%$ lower than that of epoxy $/ 6 \mathrm{wt} \% \mathrm{ZrO}_{2}$ and pure epoxy, respectively. This may be validated because of the possible cluster formation of nanoparticles in the bulk matrix which was observed in the SEM images. From Fig. 9d, one can note that the highest tensile toughness was achieved by pristine epoxy. Even a small amount of incorporation of nanoparticles tended to decrease the toughness due to the increase in brittleness of the composite. The manipulation of the morphological architecture after the introduction of nanoparticles might have caused poor adhesion between the filler and the matrix resulting in diminished toughness of the composites [38]. The restriction of polymer chain movement after incorporation of nanoparticles might have compromised the ductility and the ability of the polymer to transfer the load uniformly within the matrix. It can be concluded that there should be an optimal amount of filler in the base matrix which proves to be effective in increasing the overall tensile characteristics without compromising the structural integrity.

The tensile strength and modulus of epoxy/ $/ \mathrm{ZO}_{2}$ composites were also predicted by utilizing several theoretical models. With the help of these empirical relations, 
the effect of interfacial adhesion of the polymer composites can be analyzed. Three models were employed to evaluate the tensile strength. The first model was the Nicolais-Narkis model [39] for the relative tensile strength (RTS) given by:

$$
\mathrm{RTS}=\left(1-\mathrm{K} . \varnothing^{\prime\left(\frac{2}{3}\right)}\right)
$$

where $\emptyset^{\prime}$ is the corrected volume fraction, which accounts for the non-linearity arising due to the aspect ratio, size, and large surface area of the nanoparticles. Taking into consideration the above factors, $\varnothing^{\prime}$ can be represented by:

$$
\varnothing '=\varnothing \cdot \lambda
$$

where $\lambda$ represents the additive factor, according to:

$$
\lambda=\mathrm{a} \cdot \mathrm{A}_{\mathrm{f}}^{\mathrm{b}}
$$

where $A_{f}$ is the aspect ratio considered to be 2 [25], and a and $\mathrm{b}$ are the empirical constants accounting non-linear behavior of the nanofillers. Volume fraction $(\varnothing)$ of $\mathrm{ZrO}_{2}$ in the epoxy matrix is determined using the relation:

$$
\varnothing_{\mathrm{i}}=\frac{\mathrm{w}_{\mathrm{i}} / \rho_{\mathrm{i}}}{\sum\left(\mathrm{w}_{\mathrm{i}} / \rho_{\mathrm{i}}\right)}
$$

where $w_{i}$ and $\rho_{i}$ represent the weight fraction and density of the $i^{\text {th }}$ component, respectively. The density values of epoxy and $\mathrm{ZrO}_{2}$ were 1.25 and $5.68 \mathrm{~g} / \mathrm{cm}^{3}$, respectively. The $\mathrm{K}$ value used in the Eq. $\mathrm{C}$ is a measure of the matrixfiller interfacial adhesion. A $\mathrm{K}$ value of 1.21 denotes poor adhesion while lower values depict improved adhesion [39]. The Nielsen model, which is based on the porosity theory, includes a stress concentration factor $\tau$ as follows:

$$
\mathrm{RTS}=\exp \left(-\tau \cdot \phi^{\prime}\right)
$$

Increased values of $\tau$ indicate poor adhesion which is generally attributed to stress concentration effect [38-43]. The Turcsanyi model $[44,45]$ includes a parameter B' that increases with improved interfacial adhesion as per the equation given by:

$$
\mathrm{RTS}=\frac{1-\phi^{\prime}}{1+2.5 \cdot \phi^{\prime} . \exp \left(\mathrm{B}^{\prime} . \phi^{\prime}\right)}
$$

The results from these empirical models are plotted in Fig. 10 and their respective parameter values are tabulated in Table I. The results from the Nicolais-Narkis model showed a good match with the experimental values. It was observed that the parameter $\mathrm{K}$ from the Nicolais-Narkis model showed a value less than 1.21 , which suggested better adhesion implying the enhanced interfacial interactions. The Nielsen model also showed a similar trend when compared to the experimental values implying improved adhesion at the interface. However, the Turcsanyi model showed an excellent match with the experimental results, as can be observed in Fig. 10. B' value of 2.5 indicated an appreciable filler adhesion in the epoxy matrix.

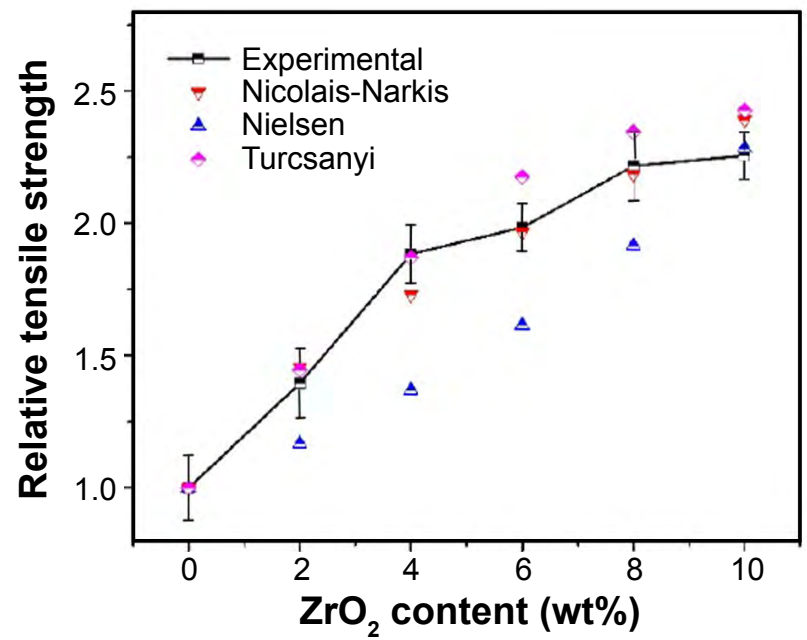

Figure 10: Plot of relative tensile strength (RTS) as a function of $\mathrm{ZrO}_{2}$ content of the composites.

[Figura 10: Gráfico da resistência à tração relativa (RTS) em função do teor de $\mathrm{ZrO}_{2}$ dos compósitos.]

Table I - Values of a, b, and characteristic parameter for the three models of relative tensile strength (RTS).

[Tabela I - Valores de a, b e parâmetro característico para os três modelos RTS.]

\begin{tabular}{ccccc}
\hline Model & $\mathrm{a}$ & $\mathrm{b}$ & Parameter & Value \\
\hline Nicolais-Narkis & 1.1 & 2.2 & $\mathrm{~K}$ & -5.7 \\
Nielsen & -5.3 & 0.9 & $\tau$ & 3.5 \\
Turcsanyi & -3.4 & 3.0 & $\mathrm{~B}^{\prime}$ & 2.5 \\
\hline
\end{tabular}

Furthermore, three theoretical models have been proposed to analyze the tensile modulus: Halpin-Tsai, Kerner's, and Sato-Furukawa. The modified Kerner's model [46-48], which considers the effect of interfacial adhesion, includes matrix volume fraction and Poisson's ratio for the relative tensile modulus (RTM) according to:

$$
\mathrm{RTM}=1+\frac{\phi^{\prime} \cdot 15 \cdot(1-v)}{1-\varnothing^{\prime} \cdot(8-10 \cdot v)}
$$

where $v$ is the Poisson's ratio of the epoxy taken as 0.33 [16]. Next, the Halpin-Tsai model $[49,50]$ is given by:

$$
\begin{aligned}
& \mathrm{RTM}=\left(\frac{3}{8} \frac{1+2 \cdot \phi^{\prime} \cdot \eta_{\mathrm{e}}}{1-\eta_{\mathrm{e}} \phi^{\prime}}+\frac{5}{8} \cdot \frac{1+2 \cdot \eta_{\mathrm{T}} \cdot \phi^{\prime}}{1-\eta_{\mathrm{T}} \cdot \phi^{\prime}}\right) \\
& \eta_{\mathrm{e}}=\frac{\delta-1}{\delta-2 \cdot \mathrm{A}_{\mathrm{f}}} \\
& \eta_{\mathrm{T}}=\frac{\delta-1}{\delta+2}
\end{aligned}
$$

where $\delta$ is the ratio of the nanofiller modulus to the matrix modulus without $\mathrm{ZrO}_{2}$. The filler modulus has been given a value of $100 \mathrm{GPa}$ [51]. Further, the Sato-Furukawa model also considers an adhesion factor $\xi$ which varies from 0 to 1. The lowest value means the existence of perfect adhesion, whereas the highest value denotes no adhesion at all. The 
equation for this model is given by:

$$
\begin{aligned}
& \mathrm{RTM}=\left[1+\frac{\left(\phi^{\prime}\right)^{2 / 3}}{2-2 \cdot\left(\phi^{\prime}\right)^{1 / 3}}(1-\psi \cdot \xi)-\frac{\left(\phi^{\prime}\right)^{2 / 3} \cdot \psi \cdot \xi}{\left[1-\left(\phi^{\prime}\right)^{1 / 3}\right]}\right] \\
& \psi=\frac{\phi^{\prime}}{3} \frac{1+\left(\phi^{\prime}\right)^{1 / 3}-\left(\phi^{\prime}\right)^{2 / 3}}{1-\left(\phi^{\prime}\right)^{1 / 3}+\left(\phi^{\prime}\right)^{2 / 3}}
\end{aligned}
$$

Fig. 11 shows the plot of experimental RTM compared with numerically computed values. The modulus value was observed to increase with the increase in nanoparticle content. The values of a, b, and the characteristic parameter are tabulated in Table II. The results from all three models showed a similar trend, and a good fit of these models was seen at epoxy loaded with 6 and $10 \mathrm{wt} \%$ of $\mathrm{ZrO}_{2}$. Deviations in the theoretical values can be accounted for the imperfect adhesion between the matrix and the filler. Due to the nonlinear trend in the values of experimental relative tensile modulus, the theoretically computed values seem to be slightly off-track from the expected trend, thus having a negative impact on the modulus. However, with $\xi$ value of 0.1 for the Sato-Furukawa model, it can be said that there was a good adhesion of the nanofillers with the bulk epoxy. A similar $\xi$ value was reported for the blending of $\mathrm{SiO}_{2}$ and multiwalled carbon nanotubes with high-density polyethylene composites [52].

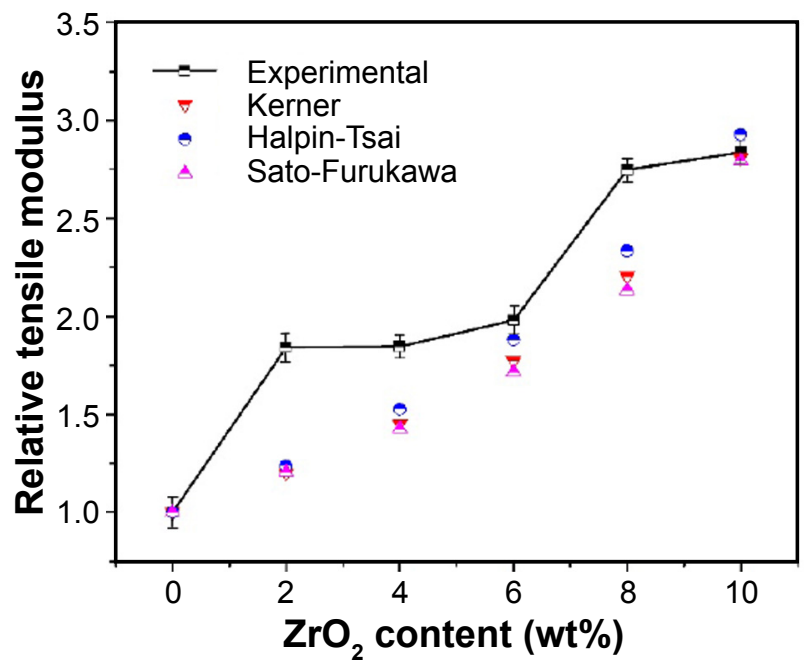

Figure 11: Plot of relative tensile modulus (RTM) as a function of $\mathrm{ZrO}_{2}$ content of the composites.

[Figura 11: Gráfico do módulo de elasticidade à tração relativo (RTM) em função do teor de $\mathrm{ZrO}{ }_{2}$ dos compósitos.]

Table II - Values of $a, b$, and characteristic parameter for the three models of relative tensile modulus (RTM).

[Tabela II - Valores de a, b e parâmetro característico para os três modelos de RTM.]

\begin{tabular}{ccccc}
\hline Model & $\mathrm{a}$ & $\mathrm{b}$ & Parameter & Value \\
\hline Halpin-Tsai & 7.7 & 1.1 & - & - \\
Kerner & 9.6 & 1.0 & - & - \\
Sato-Furukawa & 11.0 & 1.1 & $\xi$ & 0.1 \\
\hline
\end{tabular}

Compressive properties: the compressive stress-strain curves of the as-prepared composites with varying $\mathrm{ZrO}_{2}$ amounts is shown in Fig. 12. The composites somewhat deviate from linearity in terms of the compressive modulus observed. Apart from the longitudinal strength of compression, the reinforcements present in the matrix also affect the stiffness of the overall composite [53]. Fig. 13 shows the experimentally determined compressive strength and compressive modulus in terms of filler fraction present in epoxy. The compressive strength reached the highest value of $181.5 \mathrm{MPa}$ for the epoxy $/ 6 \mathrm{wt} \% \mathrm{ZrO}_{2}$, which was $33 \%$ higher than that of pure epoxy having a compressive strength of only 135.8 MPa (Fig. 13a). It appears from Fig. 13a that the compressive strength of the composites increased linearly with the increase in filler content up to $6 \mathrm{wt} \%$. Beyond this point, the increase in $\mathrm{ZrO}_{2}$ content failed to enhance the compressive strength of the composites. There was $8 \%$ and $17 \%$ drops in the compressive strengths of epoxy loaded with 8 and $10 \mathrm{wt} \% \mathrm{ZrO}$, respectively, compared to epoxy/6 $\mathrm{wt} \% \mathrm{ZrO}_{2}$. The decrease in these values can be validated due to the agglomeration of nanoparticles and the poor interaction between the filler and the polymer. The clusters created might have caused an early fracture to the composites when subjected to shear compressive load. Observing Fig. $13 \mathrm{~b}$, we can say that the compressive modulus increased in the following rank: pure epoxy $(2822 \mathrm{MPa})<$ epoxy/4 wt $\% \mathrm{ZrO}_{2}(2834 \mathrm{MPa})<$ epoxy $/ 2 \mathrm{wt} \% \mathrm{ZrO}_{2}(3298 \mathrm{MPa})<$ epoxy $/ 8 \mathrm{wt} \% \mathrm{ZrO}_{2}(3302 \mathrm{MPa})<$ epoxy $/ 10 \mathrm{wt} \% \mathrm{ZrO}_{2}(3889$ $\mathrm{MPa})<$ epoxy/6 wt\% $\mathrm{ZrO}_{2}(4193 \mathrm{MPa})$. The highest value of compressive modulus of epoxy/6 $\mathrm{wt} \% \mathrm{ZrO}_{2}$ was $48.6 \%$ higher than pure epoxy. This anomalous behavior might be explained due to the poor dispersion and slight aggregation of the nanoparticles inside the epoxy phase. The optimal values were observed for the epoxy/6 $\mathrm{wt} \% \mathrm{ZrO}_{2}$ implying a high load-bearing capability and uniform distribution of nanoparticles inside the epoxy matrix. Beyond this limit,

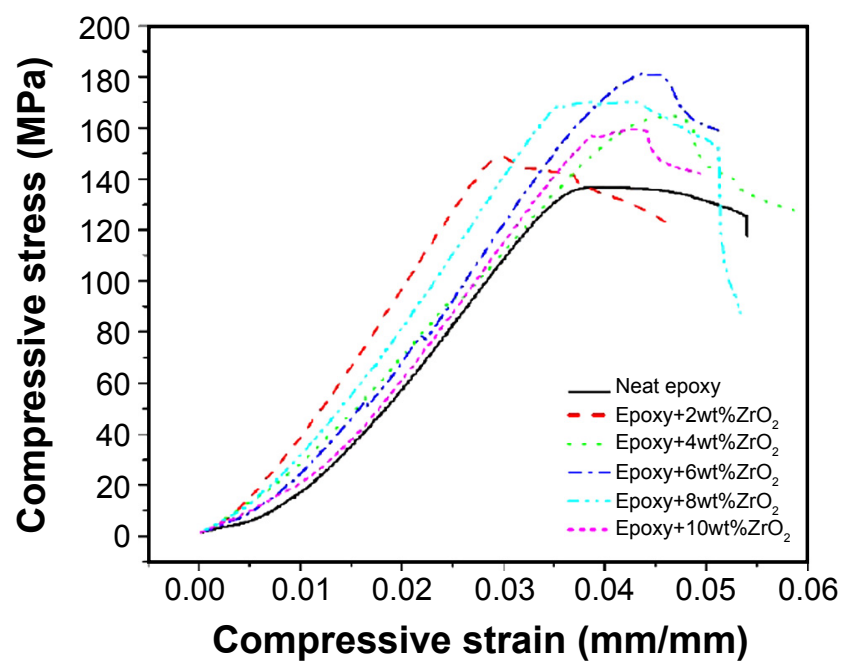

Figure 12: Compressive stress-strain curves of different types of epoxy/ZrO $\mathrm{Zr}_{2}$ composites.

[Figura 12: Curvas tensão-deformação em compressão de diferentes tipos de compósitos epóxi/ $\mathrm{ZrO}_{2}$.] 

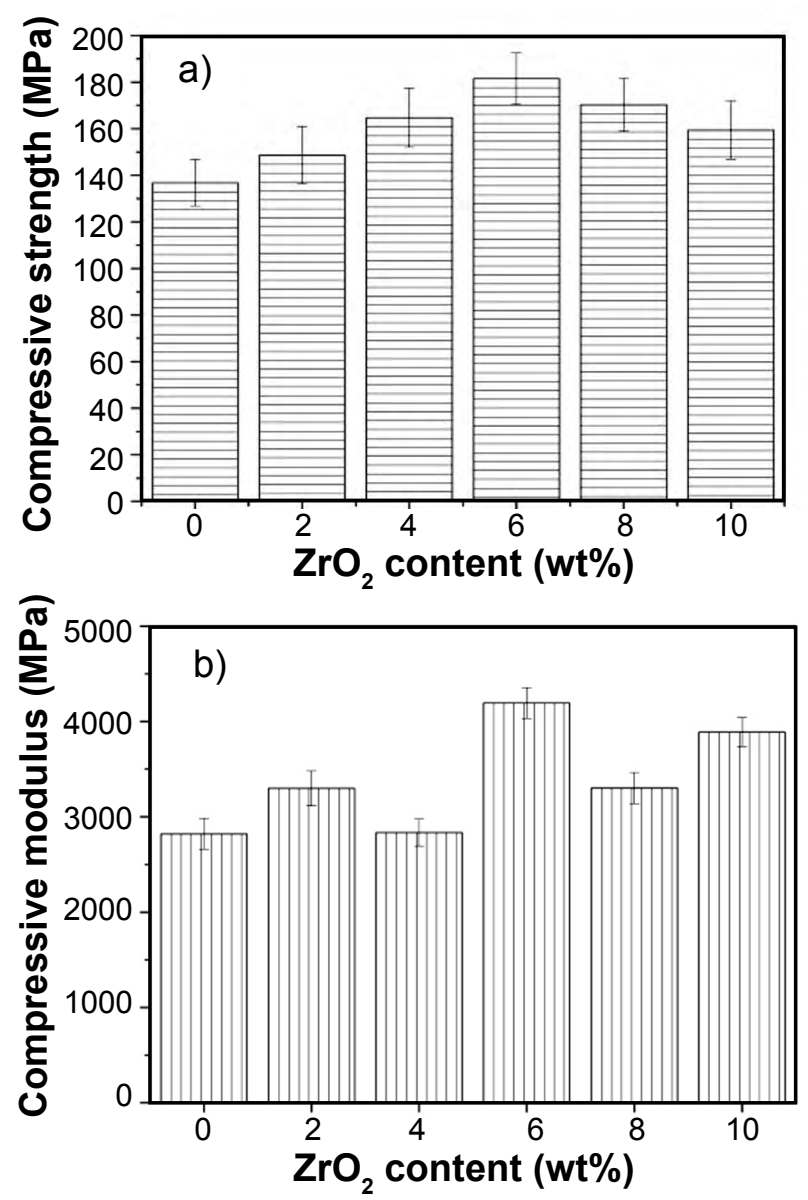

Figure 13: Results of compressive strength (a) and compressive modulus (b) of composites with different $\mathrm{ZrO}_{2}$ content.

[Figura 13: Resultados da resistência à compressão (a) e módulo de elasticidade em compressão (b) de compósitos com diferentes teores de $\mathrm{ZrO}_{2}$.]

the agglomeration of nanoparticles dominated, producing undesirable results.

Glass transition temperature: thermosetting polymers which exhibit enhanced insulating characteristics at temperatures below $\mathrm{T}_{\mathrm{g}}$ might display the semiconducting characteristics at temperatures above $\mathrm{T}_{\mathrm{g}}$ [54]. Thus, $\mathrm{T}_{\mathrm{g}}$ can be considered as an important parameter of epoxy resins. Fig. 14a shows the DSC thermograms of the epoxy/ $\mathrm{ZrO}_{2}$ composites with respective $\mathrm{T}_{\mathrm{g}}$ values in Fig. $14 \mathrm{~b}$. The $\mathrm{T}_{\mathrm{g}}$ values appeared to increase steadily from 0 to $4 \mathrm{wt} \%$ of $\mathrm{ZrO}_{2}$, after which there was a marginal drop in the $\mathrm{T}_{\mathrm{g}}$ value for the nanofiller composite containing $6 \mathrm{wt} \% \mathrm{ZrO}_{2}$. The $\mathrm{T}_{\mathrm{g}}$ further increased and reached a maximum value $\left(129.4^{\circ} \mathrm{C}\right)^{\mathrm{g}}$ for epoxy-containing $10 \mathrm{wt} \% \mathrm{ZrO}_{2}$, which was $\sim 16 \%$ higher than the nanoparticle-free epoxy. Various factors including filler-matrix interface contact, cross-linking density, and polymer chain segment mobility come into picture while examining $T_{g}$ values of thermoset polymers. The observed enhancement in the $T_{g}$ values of the composites can be explained by the restriction of mobile chain segments of the bulk epoxy due to the filler-matrix adhesion. It can also be reasoned out due to the uniformly distributed nano- $\mathrm{ZrO}_{2}$ in
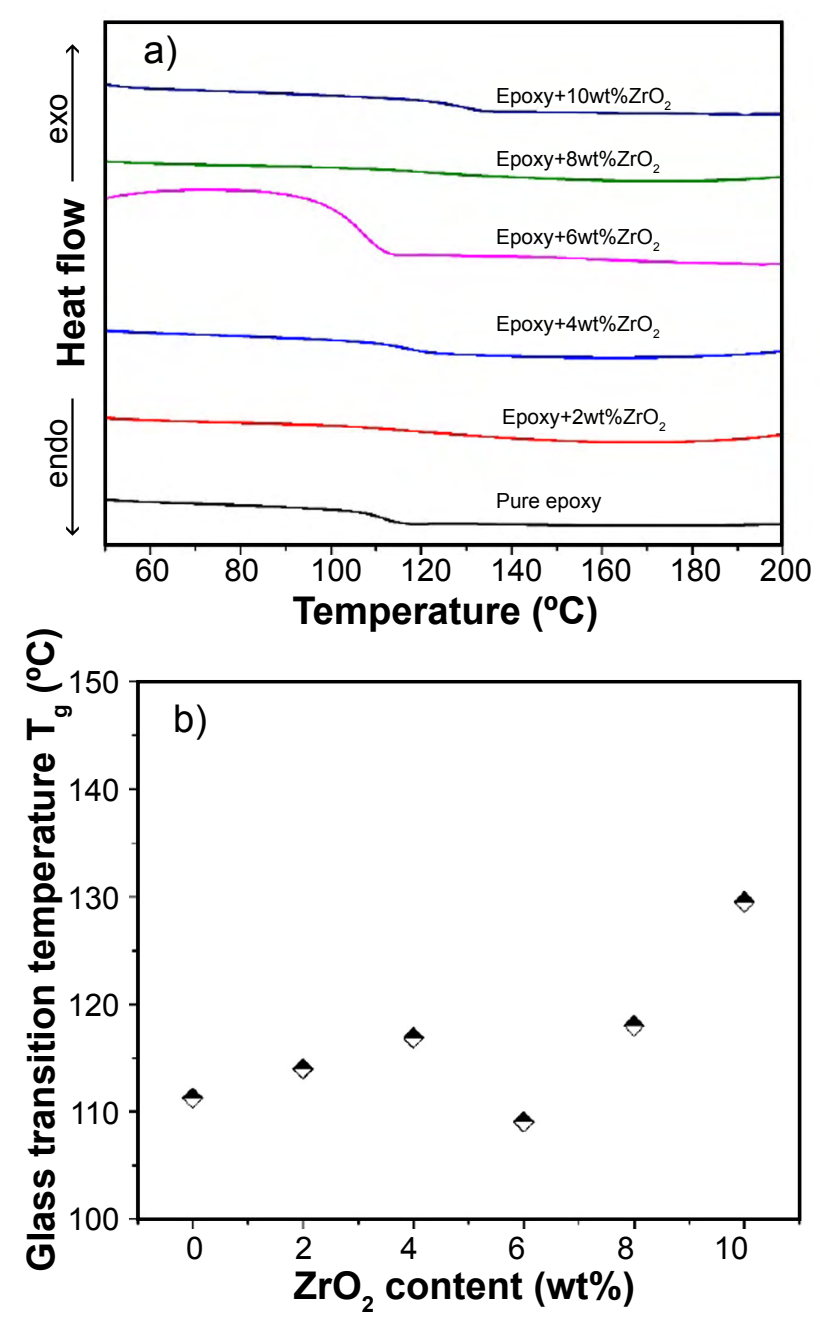

Figure 14: DSC curves of epoxy composites with varying $\mathrm{ZrO}_{2}$ content (a) and glass transition temperature $\left(\mathrm{T}_{\mathrm{g}}\right)$ of the composites as a function of nanoparticle content (b).

[Figura 14: Curvas de DSC de compósitos de epóxi com diferentes teores de $\mathrm{ZrO}_{2}(a)$ e temperatura de transição vítrea $\left(T_{g}\right)$ dos compósitos em função do teor de nanopartículas (b).]

the matrix. As the loading is uniform, the particle-matrix interface would have good adhesion hindering the polymer chain mobility which results in elevate $T_{g}$ [37]. However, a marginal drop in the $\mathrm{T}_{\mathrm{g}}$ value was observed for the epoxy $/ 6 \mathrm{wt} \% \mathrm{ZrO}_{2}$ composite. This might be possible due to the reduction in cross-linking density at the vicinity of the particle-matrix interface and non-uniform dispersion of nanoparticles in epoxy. This would cause a downward shift in the $\mathrm{T}_{\mathrm{g}}$ value at a fairly high content of nanoparticles.

$A C$ breakdown strength: the breakdown voltage of the composites was observed to reach its maximum value for epoxy $/ 2 \mathrm{wt} \% \mathrm{ZrO}_{2}$ and the minimum value was observed for epoxy/10 wt $\% \mathrm{ZrO}_{2}$ which was a little more than pure epoxy (Fig. 15). The optimum amount of filler concentration, in this case, was found to be $2 \mathrm{wt} \%$ of $\mathrm{ZrO}_{2}$ in the matrix, which showed a threshold voltage of $\sim 15 \mathrm{kV}$. This value was $\sim 12 \%$ higher than that of the pure epoxy. The high surface area of nano- $\mathrm{ZrO}_{2}$ resulted in the altered behavior of 
the polymer matrix, which in turn improved the interfacial area. Further increase in the filler concentration tended to decrease the breakdown voltage drastically as observed in Fig. 15. The optimal value shown by epoxy $/ 2 \mathrm{wt} \% \mathrm{ZrO}_{2}$ might be due to the high amount of epoxy present near the vicinity of the nanoparticles, also referred to as the high interaction zone. It may be assumed that because of this, the accumulated charge at any point in the threshold field is reduced which alters the distribution of space charge [14]. In addition, the fillers incorporated into the epoxy matrix tend to act as scattering sites where the electrons fail to gain the momentum necessary to the disruption of the applied high voltage. Due to the applied electric field, electrons tend to accelerate and collide directly with the incorporated nanoparticles failing to attain momentum. This mechanism ceases the electrons to cause any catastrophic failure in the equipment and insulation $[55,56]$. Hence, epoxy/ZrO composites have enhanced electrical breakdown strength in contrast to the control sample, under high AC voltage.

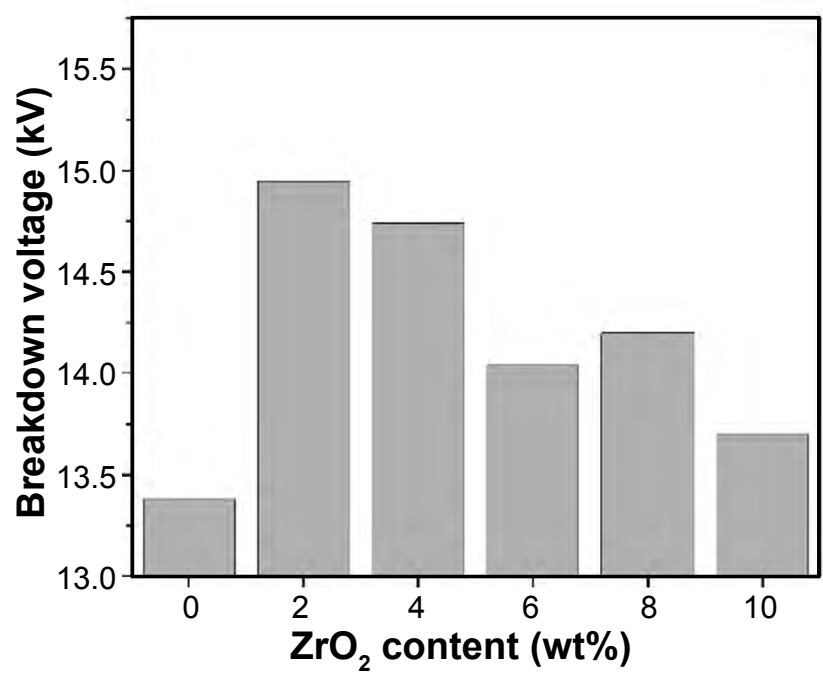

Figure 15: Breakdown voltage of epoxy/ $\mathrm{ZrO}_{2}$ composites as a function of $\mathrm{ZrO}_{2}$ content.

[Figura 15: Tensão de ruptura dielétrica de compósitos epóxi/ZrO em função do teor de $\mathrm{ZrO}_{2}$.]

\section{CONCLUSIONS}

Epoxy composites were loaded with gel combustionderived nano- $\mathrm{ZrO}_{2}$ having a cubic phase with varying weight fractions $(2-10 \mathrm{wt} \%)$. The ultrasonication method was employed to obtain a uniform distribution of the nanoparticles in the epoxy matrix. Results revealed that the tensile characteristics of the composites increased linearly with nanoparticle concentration in the matrix. The highest tensile strength was obtained for epoxy $/ 10 \mathrm{wt} \% \mathrm{ZrO}_{2}$, which was $125 \%$ more than the pristine epoxy. The maximum Young's modulus was also achieved at the same content which was $184 \%$ higher than the control sample. However, the tensile toughness and the elongation at break appeared to diminish at a high concentration of nanoparticles. This was attributed to the agglomerations of nanoparticles formed at increased loading fractions which were observed in the SEM micrographs. The optimal compressive properties were noted for the epoxy loaded with $6 \mathrm{wt} \% \mathrm{ZrO}_{2}$. A maximum elevation of $16 \%$ in $\mathrm{T}_{\mathrm{g}}$ for epoxy $/ 10 \mathrm{wt} \% \mathrm{ZrO}_{2}$ was observed with respect to the pristine sample. The experimental tensile properties were compared with the mathematical model values. All the tested models showed similar trends in comparison with experimental values. Among the tested models, Nicolais-Narkis and Turcsanyi models were in good agreement with the experimental values for tensile strength and Sato-Furukawa model for tensile modulus. The AC breakdown voltage of the nanofiller composite was also observed to be high compared to $\mathrm{ZrO}_{2}$-free epoxy. Hence, these composites can be employed as main slot insulating materials in electric machines and also as insulation in transformers between high-voltage winding and transformer tanks. They can also be employed in power equipment that needs high-breakdown voltage coupled with appreciable thermal, tensile, and compressive parameters.

\section{REFERENCES}

[1] T. Tanaka, G.C. Montanari, R. Mulhaupt, IEEE Trans. Dielectr. Electr. Insul. 11, 5 (2004) 763.

[2] D. Liu, W. Zhao, S. Liu, Q. Cen, Q. Xue, Surf. Coat. Technol. 286 (2016) 354.

[3] T.C. Triantafillou, N. Plevris, Mater. Struct. 25, 4 (1992) 201.

[4] K.-Y. Park, S.-E. Lee, C.-G. Kim, J.-H. Han, Compos. Struct. 81, 3 (2007) 401.

[5] B. Abramoff, J. Covino, J. Appl. Polym. Sci. 46, 10 (1992) 1785.

[6] Y. Huang, Y. Tian, Y. Li, X. Tan, Q. Li, J. Cheng, J. Zhang, RSC Adv. 7, 77 (2017) 49074.

[7] M. Khan, A.A. Khurram, T. Li, T. Zhao, T. Subhani, I.H. Gul, Z. Ali, V. Patel, J. Mater. Sci. Technol. 34, 12 (2018) 2424.

[8] H.N. Chrakala, B. Ramaraj, Shivakumaraiah, G.M. Madhu, Siddaramaiah, J. Mater. Sci. 47, 23 (2012) 8076.

[9] J.K. Rao, A. Raizada, D. Ganguly, M.M. Mankad, S.V. Satyanarayana, G.M. Madhu, Polym. Bull. 72, 8 (2015) 2033.

[10] J.K. Rao, A. Raizada, D. Ganguly, M.M. Mankad, S.V. Satyanarayana, G.M. Madhu, J. Mater. Sci. 50, 21 (2015) 7064.

[11] H.N. Chrakala, B. Ramaraj, Shivakumaraiah, G.M. Madhu, Siddaramaiah, J. Alloys Compd. 551 (2013) 531.

[12] H.N. Chrakala, B. Ramaraj, Shivakumaraiah, G.M. Madhu, Siddaramaiah, J. Phys. Chem. C 117, 9 (2013) 4771. [13] M.W. Khan, S.U. Asif, K.M. Ur Rehman, W. Uddin, Mubasher, S. Ahmed, E.U. Khan, A. Tagliaferro, P. Jagdale, M. Fakhar-e-Alam, Physica B Condens. Matter 556 (2019) 17.

[14] A. Mohanty, V.K. Srivastava, Mater. Des. 47 (2013) 711.

[15] S. Kumar Singh, A. Kumar, A. Jain, Mater. Today Proc. 


\section{5, 2 (2018) 6339.}

[16] H.A. Al-Turaif, Prog. Org. Coat. 69, 3 (2010) 241.

[17] A.A. Azeez, K.Y. Rhee, S.J. Park, D. Hui, Compos. B Eng. 45, 1 (2013) 308.

[18] G.K. Raju, G.M. Madhu, M.A. Khan, P. Reddy, Mater. Today Proc. 5 (2018) 27998.

[19] G. Gusmano, G. Montesperelli, M. Rapone, G. Padeletti, A. Cusmà, S. Kaciulis, A. Mezzi, R. Di Maggio, Surf. Coat. Technol. 201, 12 (2007) 5822.

[20] J.F. Quinson, C. Chino, A.M. De Becdelievre, C. Guizard, M. Brunel, J. Mater. Sci. 31, 19 (1996) 5179.

[21] R.V. Kurahatti, A.O. Surendranathan, S. Srivastava, N. Singh, A.V. Ramesh Kumar, B. Suresha, Mater. Des. 32, 5 (2011) 2644.

[22] A. Balamurugan, S. Kannan, S. Rajeswari, Mater. Lett. 57, 26-27 (2003) 4202.

[23] R. Medina, F. Haupert, A.K. Schlarb, J. Mater. Sci. 43, 9 (2008) 3245.

[24] S. Halder, P.K. Ghosh, M.S. Goyat, High Perform. Polym. 24, 4 (2012) 331.

[25] S. Halder, M. Goyat, P. Ghosh, High Perform. Polym. 28, 6 (2016) 697.

[26] S. Halder, S. Ahemad, S. Das, J. Wang, ACS Appl. Mater. Interfaces 8, 3 (2016) 1695.

[27] P.T. Chung, C.T. Yang, S.H. Wang, C.W. Chen, A.S.T. Chiang, C.-Y. Liu, Mater. Chem. Phys. 136, 2-3 (2012) 868. [28] P. Tao, Y. Li, R.W. Siegel, L.S. Schadler, J. Appl. Polym. Sci. 130, 5 (2013) 3785.

[29] J. Li, C. Peng, Z. Li, Z. Wu, S. Li, RSC Adv. 6, 66 (2016) 61393.

[30] X. Ma, C. Peng, D. Zhou, Z. Wu, S. Li, J. Wang, N. Sun, J. Sol-Gel Sci. Technol. 88, 2 (2018) 442.

[31] J.M. Matos, F.A. Júnior, L.S. Cavalcante, V. Santos, S.H. Leal, L.S. Júnior, M.R. Santos, E. Longo, Mater. Chem. Phys. 117 (2009) 455.

[32] P. Rosso, L. Ye, Macromol. Rapid Commun. 28 (2007) 121.

[33] S.N. Basahel, T.T. Ali, M. Mokhtar, K. Narasimharao, Nanoscale Res. Lett. 10, 73 (2015).

[34] J.C. Valmalette, M. Isa, Chem. Mater. 14 (2002) 5098.

[35] R. Nagaraja, N. Kottam, C.R. Girija, B.M.
Nagabhushana, Powder Technol. 215 (2012) 91.

[36] S. Chhetri, N.C. Adak, P. Samanta, N.C. Murmu, T. Kuila, Polym. Test. 63 (2017) 1.

[37] M.S. Goyat, S. Rana, S. Halder, P.K. Ghosh, Ultrason. Sonochem. 40 (2018) 861.

[38] A.J. Kinloch, R.D. Mohammed, A.C. Taylor, C. Eger, S. Sprenger, D. Egan, J. Mater. Sci. 40, 18 (2005) 5083.

[39] L. Nicolais, M. Narkis, Polym. Eng. Sci. 11, 3 (1971) 194.

[40] E.D. Bliznakov, C.C. White, M.T. Shaw, J. Appl. Polym. Sci. 77, 14 (2000) 3220.

[41] D. Metin, F. Tihminlioğlu, D. Balköse, S. Ülkü, Compos. A Appl. Sci. Manuf. 35, 1 (2004) 23.

[42] T. Kunori, P.H. Geil, J. Macromol. Sci. B 18, 1 (1980) 135.

[43] L.E. Nielsen, J. Compos. Mater. 1, 1 (1967) 100.

[44] B. Turcsanyi, B. Pukanszky, F. Tudos, J. Mater. Sci. Lett. 7 (1988) 160.

[45] S.Y. Fu, X.Q. Feng, B. Lauke, Y.W. Mai, Compos. B Eng. 39 (2008) 933.

[46] J.G.L. Beijer, J.L. Spoormker, Polymer 41 (1988) 5443. [47] R. Abraham, S.P. Thomas, S. Kuryan, J. Isac, K.T. Varughese, S. Thomas, Express Polym. Lett. 3 (2009) 177. [48] E.H. Kerner, Proc. Phys. Soc. B 69 (1954) 808.

[49] A.P. Mathew, K. Oksman, M. Sain, J. Appl. Polym. Sci. 97 (2004) 2014.

[50] J.C. Halpin, J.L. Kardos, Polym. Eng. Sci. 16 (1976) 344.

[51] AZO Materials, "Zirconia- $\mathrm{ZrO}_{2}$ zirconium dioxide", https://www.azom.com, ac. 11/08/2019.

[52] T.A. Praveen, J. Sundara Rajan, R.R.N. Sailaja, Mater. Res. Bull. 83 (2016) 294.

[53] S.N.A. Safri, M.T.H. Sultan, N. Saba, M. Jawaid, Polym. Test. 71 (2018) 362.

[54] T.S. Radoman, J.V. Džunuzović, K.B. Jeremić, B.N. Grgur, D.S. Miličević, I.G. Popović, E.S. Džunuzović, Mater. Des. 62 (2014) 158.

[55] R. Sarathi, R.K. Sahu, P. Rajeshkumar, Mater. Sci. Eng. A 445-446 (2007) 567.

[56] Z. Li, K. Okamoto, Y. Ohki, T. Tanaka, IEEE Trans. Dielectr. Electr. Insul. 17, 3 (2010) 653.

(Rec. 12/11/2019, Rev. 23/01/2020, Ac. 24/01/2020) 